\title{
Инновации в прабалтийском и прасдавянском списках Сводеша как аргумент в споре о бадтосдавянском единстве
}

\begin{abstract}
В статье делается попытка сопоставления праславянского и прабалтийского списков Сводеша с праиндоевропейским с целью поиска общих инноваций. Применяемый метод основывается на том, что наличие периода языкового единства выражается в инновациях на всех уровнях языка, включая лексический. Таким образом, разумно для определения степени родства использовать не общее количество совпадений в списке Сводеша, а количество общих инноваций по сравнению с праязыком. При сравнении праславянского и прабалтийского стословного списков с праиндоевропейским было найдено 14 общих инноваций (10 при более строгом подходе). По мнению автора, это может служить веским доводом в пользу существования периода балтославянского единства.

Ключевые слова: лексикостатистика, славянские языки, балтийские языки, праиндоевропейский язык.
\end{abstract}

Вопрос о существовании балтославянского праязыка имеет долгую историю. До конца XIX века балтийские и славянские языки практически безоговорочно признавали потомками единого праязыка. Сомнения в справедливости этого положения высказывались неоднократно, однако без должной аргументации. Переломным моментом стало появление концепции А. Мейе [Meillet, 1908: 40-48], согласно которой сходства между славянскими и балтийскими языками объясняются параллельным развитием. Я. Эндзелин попытался примирить оба взгляда, предположив, что праславянский и прабалтийский являются потомками двух разных диалектов праиндоевропейского, пережившими в определённый момент своей истории сближение, а потом снова разошедшимися. Я. Розвадовский также предложил компромиссную гипотезу, по которой за эпохой единого прабалтославянского языка последовало его распадение (которое он датирует II-I тысячелетиями до н. э.), а спустя некоторое время новое схождение и период соседских отношений (с начала нашей эры и по сей день) [Rozwadowski, 1961]. Оригинальные взгляды высказал Б. В. Горнунг, считавший, что путём постепенного диалектного дробления праиндоевропейского языка выделились прапрусскославянский и пралеттолитовский диалекты. С течением времени прапрусскославянский разделился на праславянский и прапрусский, последний при этом сблизился с пралеттолитовским [Горнунг, 1958; Горнунг, 1963: 49-50]. Отдельно следует упомянуть о гипотезах, выводящих праславянский из периферийных диалектов прабалтийского, как под влиянием субстрата (А. И. Соболевский [Соболевский, 1922: 331-332], Т. Лер-Сплавинский [Лер-Сплавинский, 1964: 136], В. Пизани [Pisani, 1969], В. В. Мартынов [Мартынов, 2004: 14-16]), так и без него (В. Н. Топоров и Вяч. Вс. Иванов [Балтийские языки 2006: 19-20]).

В ходе дискуссии высказывалось множество аргументов за и против существования единства. Описывались сходство и различие на всех уровнях языка. Критики гипотезы балтославянского единства отмечают, что многие балтославянские инновации в фонетике и морфологии не эксклюзивны, схожие процессы можно найти и в других индоевропейских языках, либо они протекали неодинаково в праславянском и прабалтийском языках.

Journal of Language Relationship • Вопросы языкового родства • 12 (2014) • Pр. 21-30 • ( С Саенко М. Н., 2014 
Таблицุ 1. Основные фонетические, морфологические и синтаксические аргументы в пользу существования балтославянского единства ${ }^{1}$

\begin{tabular}{|c|c|c|}
\hline Изоглосса & $\begin{array}{l}\text { Идентичность } \\
\text { в балт. и слав. }\end{array}$ & $\begin{array}{l}\text { Экскиюзив- } \\
\text { ность в и.-е. }\end{array}$ \\
\hline Закон Винтера & + & + \\
\hline Сатемизация & + & - \\
\hline Переход $s>\check{s}$ после $i, u, r, k$ & - & - \\
\hline 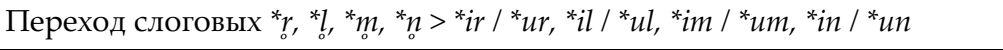 & \pm & \pm \\
\hline Устранение геминат: ${ }^{*} s S>{ }^{*} s,{ }^{*} t t>{ }^{*} s t$ & + & - \\
\hline Эпентеза $s r>s t r$ & \pm & - \\
\hline Слияние праиндоевропейских * $a$ и *o & - & - \\
\hline Переход еи > јоu & + & - \\
\hline Закон Хирта & + & + \\
\hline Закон Фортунатова-Соссюра & \pm & + \\
\hline $\begin{array}{l}\text { Переход причастий с суффиксами *nt- и *us- из согласного склонения } \\
\text { в склонение на *jo- }\end{array}$ & \pm & + \\
\hline $\begin{array}{l}\text { Переход многих существительных из склонения на согласный в более } \\
\text { продуктивные типы склонения }\end{array}$ & \pm & \pm \\
\hline $\begin{array}{l}\text { Форма Nom. sg. указательного местоимения *so вытеснена косвенной } \\
\text { основой *to- }\end{array}$ & + & - \\
\hline Вытеснение в основах на *o- формы Gen. sg. формой Abl. sg. & \pm & + \\
\hline $\begin{array}{l}\text { Образование косвенных падежей личного местоимения 1-го лица } \\
\text { от основы *men-/*mon-/*mun- }\end{array}$ & - & + \\
\hline $\begin{array}{l}\text { Введение окончаний *-mi в Ins. sg., *-mīs в Ins. pl. и *-mus в Dat. pl. } \\
\text { существительных }\end{array}$ & \pm & - \\
\hline $\begin{array}{l}\text { Формирование спряжения с суффиксами *owa-/*uj- в праславянском } \\
\text { и *av-/*auj- в прабалтийском }\end{array}$ & \pm & + \\
\hline Творительный предикативный & + & + \\
\hline Родительный при отрицании & + & + \\
\hline
\end{tabular}

По мнению критиков гипотезы балтославянского единства, судя по количеству фонетических и морфологических инноваций, результаты которых полностью или почти полностью совпадают в праславянском и прабалтийском и при этом не имеют параллелей в других группах индоевропейских языков, невозможно исчерпывающе ответить на вопрос, существовала ли прабалтославянская эпоха после распада праиндоевропейского языка. Решение проблемы можно найти, если признать, что в процессе установления языкового родства лексика не менее важна, чем фонетика и морфология. В литературе указывается, что существует очень большое количество балтославянских лексических изоглосс (из которых не менее 200 являются общими инновациями) [Дини, 2002: 164], но очень многие могут быть объяснены как эксклюзивные индоевропейские архаизмы, совместные заимствования или ареальные схождения [Даучюте, 1989: 32]. Поэтому речь идёт не о любой лексике, а о базисной (список Сводеша), которая редко заимствуется и медленно вытесняется инновациями.

${ }^{1}$ В таблицу не включены явно поздние общие инновации, например образование местоименных форм прилагательных или палатализация согласных. 
Дексикостатистика уже привлекалась для решения балтославянской проблемы. Следует упомянуть о схемах, полученных В. Зепсом [Zeps, 1985], А. Гирденисом и В. Мажюлисом [Girdenis, Mažiulis, 1994], В. Блажеком и П. Новотной [Blažek, Novotná, 2007]. Однако при подсчётах, проведённых этими исследователями, учитывалось просто общее количество совпадений между списками Сводеша балтийских и славянских языков, в то время как для генеалогической классификации языков общие инновации имеют большее значение, чем архаизмы. Поэтому получить действительно достоверный ответ на вопрос, существовал ли прабалтославянский язык или нет, можно, только если сравнить праиндоевропейский список Сводеша с праславянским и прабалтийским и определить, есть ли в праславянском и прабалтийском общие инновации и насколько их много.

Таблица 2. Сопоставление праславянского и прабалтийского стословных списков с праиндоевропейским ${ }^{2}$

\begin{tabular}{|c|c|c|c|c|}
\hline англ. & праслав. & прабалт. & п.-и.-е. (Адамс) & п.-и.-е. (автор) \\
\hline 1. all & ${ }^{*} w b x b$ & *wisas & ${ }^{*} w i \hat{k}-$ & *pant- \\
\hline 2. ashes & *pepelb/*popelb & *pelena- & *h $h_{2} \mathrm{~h}_{x} \bar{o} s$ & ${ }^{*} x o H s s$ \\
\hline 3. bark & *(s)kora & *žeinwē & ${ }^{* l o u b h o / e a^{-}}$ & ${ }^{*} k o r-$ \\
\hline 4. belly & *čerwo & *wēdera- & *udero- & *wedero- \\
\hline 5. big & $*$ welb $(j b)$ & *didis & ${ }^{*} m e g h_{a^{-}}$ & ${ }^{*} m e \hat{g}-$ \\
\hline 6. bird & ${ }^{*} p r t a$ & *put- & ${ }^{*} h_{a} e w e i-$ & *awis \\
\hline 7. bite & ${ }^{*}$ kosati & ${ }^{*}$ kansti & ${ }^{*} \operatorname{den} \hat{k}-$ & ${ }^{*} \operatorname{den} \hat{k}-$ \\
\hline 8. black & *čbrnb $(j b)$ & *kirsnas & * $k^{w} r s n o ́ s$ & *krsnos \\
\hline 9. blood & *kry & ${ }^{*}$ asin- & $* h_{1} e ́ s h_{2} r$ & *esxr \\
\hline 10. bone & *kostb & *kaula- & *hóst & ${ }^{*}$ xasti \\
\hline 11. breast & *porsb & *piršis & *psténos, *speno- & *perk̂us \\
\hline 12. burn & *žekti & *dekti & ${ }^{*} d h e g^{w} h-$ & ${ }^{*} d^{h} e g^{w h}$ \\
\hline 13. cloud & ${ }^{*}$ obwolka / ${ }^{*}-o /{ }^{*}-b$ & *debesis & *nébhes- & ${ }^{*} n e b^{h}$ os \\
\hline 14. cold & ${ }^{*} x o l d b n v(j b)$ & *šāltas & *gel- & ${ }^{*}(s) \mathrm{gel}-$ \\
\hline 15. come & ${ }^{*}$ pri-joti / ${ }^{*}$ pri-xoditi & *at-eiti & ${ }^{*} g^{w} e m$ & ${ }^{*} g^{w} e m-$ \\
\hline 16. die & ${ }^{*} m e r t i$ & ${ }^{*}$ mirti & ${ }^{*}$ mer- & ${ }^{*}$ mer- \\
\hline 17. dog & ${ }^{*} p b S b$ & *šūōn & $* \hat{k}(u) w \bar{o} n$ & ${ }^{*} \hat{k}(u)$ wons \\
\hline 18. drink & ${ }^{*}$ piti & ${ }^{*} p \bar{o}-$ & ${ }^{*} \operatorname{peh}_{3}(i)-$ & ${ }^{*} p o H-$ / ${ }^{*}$ piH- \\
\hline 19. dry & ${ }^{*} s u x b(j b)$ & *sausas & ${ }^{*}$ saus- & *sausos \\
\hline 20. ear & *uxo & *aussis & *háus- & *aus \\
\hline 21. earth & *zemb & *žemē & *dhéghōm & ${ }^{*} d^{h} g^{h}$ oms \\
\hline 22. eat & *ěsti & *ēsti & ${ }^{*} h_{1} e ́ d m i$ & *ed- \\
\hline 23. egg & *aje & *pautas & ${ }^{*} h_{a} \bar{o}(w)$ iom & *owjom \\
\hline 24. eye & *oko & ${ }^{*} a k i s$ & ${ }^{*} h_{3} O k^{w}$ & ${ }^{*} O k^{w}-$ \\
\hline 25. fat & ${ }^{*} t u k b$ & *taukkas & *sélpes- & ${ }^{*}$ selp- \\
\hline 26. feather & *pero & - & ${ }^{*} p e t(e) r-$ & petr \\
\hline
\end{tabular}

2 Полужирным выделены совместные инновации в праславянском и прабалтийском, а также отличия авторской реконструкции праиндоевропейского списка от реконструкции Д. Адамса [Adams, Mallory, 2006: 97-99]. 


\begin{tabular}{|c|c|c|c|c|}
\hline англ. & праслав. & прабалт. & п.-и.-е. (Адамс) & п.-и.-е. (автор) \\
\hline 27. fire & *ogn'b & *ungnis, *panu & ${ }^{*}$ péh ${ }_{2} u r$ & *pexur, ${ }^{*}$ Hngnis \\
\hline 28. fish & *ryba & *žuwis & ${ }^{*} d h \hat{g} h u h_{x^{-}}$ & ${ }^{*} d^{h} \hat{g}^{h} u H s$ \\
\hline 29. fly & *letěti & - & *pet- & *pet- \\
\hline 30. foot & *noga & *pēda & *péds & *pots \\
\hline 31. full & ${ }^{*} p b \ln b(j b)$ & *pilnas & *pllh nós & *plHnos \\
\hline 32. give & ${ }^{*}$ dati & ${ }^{*} d \bar{o} t i$ & ${ }^{*} \mathrm{deh}_{3}$ & ${ }^{*} \mathrm{doH}-$ \\
\hline 33. go & *joti & *eiti & $* h_{1} e i-$ & $*_{e i-}$ \\
\hline 34. good & ${ }^{*} \operatorname{dobrb}(j b)$ & *labas & ${ }^{*} h_{1}(e) s u-$ & ${ }^{*} \mathrm{Hsu}-$ \\
\hline 35. green & ${ }^{*} z e l e n z(j b)$ & *žaljas & $* \hat{k}_{y e h}$ & ${ }^{*} \hat{g}^{h} e l-$ \\
\hline 36. hair & *wolsb & - & *k̂kripo- & $* \hat{k r i p}-$ \\
\hline 37. hand & *roka & *rankāa & *ghhes-r- & ${ }^{*} \hat{g}^{h} e s r$ \\
\hline 38. head & *golwa & ${ }^{*}$ galwā & $* \hat{k} r r \bar{e} h_{2}$ & *kersr \\
\hline 39. hear & *slyšati & *girdèti & ${ }^{*} \hat{k}$ leu- & ${ }^{*}$ klew- \\
\hline 40. heart & *sbrdoko & *̌̌erd & *kétrd & *kerd \\
\hline 41. horn & ${ }^{*}$ rogb & *ragas & *ker- & *k̂krnom \\
\hline 42. I & ${ }^{*} a z b$ & $* e \check{z}$ & $* h_{1} e \hat{g}$ & ${ }^{*} e \hat{g}^{\left({ }^{(h)}\right.} O(m)$ \\
\hline 43. kill & *biti & *galinti & ${ }^{*} n e \hat{k}-$ & *gwhen- \\
\hline 44. knee & *kolěno & ${ }^{*} k e l i s$ & *gónu & *ôgonu \\
\hline 45. know & ${ }^{*} w e ̌ d e ̌ t i, ~ * z n a t i$ & *žināti & *weid- & *weid, * ${ }^{*} n o H-$ \\
\hline 46. leaf & *listb & *lap- & *bhel- & $* b^{h} e l-$ \\
\hline 47. lie & *ležati & ${ }^{*}$ gulti & $* \hat{k} e i-$ & *kei- \\
\hline 48. liver & *ętro & *jeknā & ${ }^{*} y^{\prime} k^{w} r(t)$ & $*_{j e k}^{w} \underset{o}{r}$ \\
\hline 49. long & ${ }^{*} d b \lg b(j b)$ & *ilgas & *dlh ${ }_{1}$ ghós & ${ }^{*} d l \mathrm{Hg}^{h} \mathrm{OS}$ \\
\hline 50. louse & $*_{w b s ̌ b}$ & *ut- & $* l u-$ & $* l u-$ \\
\hline 51. man & ${ }^{*} m Q z ̌ z$ & *wiras & ${ }^{*} h_{1} n \bar{e} r$ & ${ }^{*}$ wiHros \\
\hline 52. man (person) & *čelowěkb & *žmōn & ${ }^{*} d^{h} \hat{g}^{h} m-o ́ n-$ & *manus \\
\hline 53. many, much & ${ }^{*}$ mbnogo & *daug- & *pélh 1 us & ${ }^{*}$ polHu \\
\hline 54. meat & ${ }^{*} m e ̨ s o$ & ${ }^{*} m e n s \bar{a}$ & *(s)kwéh tis & ${ }^{*} m e H m s$ \\
\hline 55. moon & *luna, *měsękb & ${ }^{*} m \bar{e} n \bar{n} n$ & *méh ${ }_{1} n \bar{t} t$ & ${ }^{*} m e H n-$ \\
\hline 56. mountain & *gora & *kalnas & ${ }^{*} g^{w}{ }^{w} h_{x^{-}}$ & $* g^{w}$ orHs \\
\hline 57. mouth & *usta & *austā & ${ }^{*} h_{1 / 4} o ́ h_{1}(e) s-$ & ${ }^{*} \mathrm{HoHos}$ \\
\hline 58. nail & *nogztb & *nagas & $* h_{3} n o g h(w)-$ & ${ }^{*} \mathrm{HnogHos}$ \\
\hline 59. name & *jome & *inmen & *hn nómn & *noHmen \\
\hline 60. neck & *̌̌bja & *kaklas & ${ }^{*}$ moni- & *mon- \\
\hline 61. new & ${ }^{*}$ nowb $(j b)$ & *nawas/*njaujas & *néwos & ${ }^{*}$ newos \\
\hline 62. night & *noktb & *naktis & ${ }^{*} n e k^{w} t-$ & ${ }^{*} n o k^{w} t s$ \\
\hline 63. nose & ${ }^{*}$ nosb & *nāsis & *h $h_{x} n a ́ s s$ & *nass \\
\hline 64. not & *ne & ${ }^{*} n \bar{e}$ & *ne & *ne \\
\hline 65. one & *edinz / *edsnb & *ainas & ${ }^{*} h_{1}$ oin- & ${ }^{*} \mathrm{oi},{ }^{*}$ soms \\
\hline 66. rain & $* d r z \check{z} \breve{b} b$ & *leitus & ${ }^{*} h_{1}$ wers- & *suH- \\
\hline
\end{tabular}




\begin{tabular}{|c|c|c|c|c|}
\hline англ. & праслав. & прабалт. & п.-и.-е. (Адамс) & п.-и.-е. (автор) \\
\hline 67. red & *čerw $\left(l^{\prime}\right) e n z(j b)$ & *raudas & ${ }^{*} h_{1}$ reudh- & ${ }^{*}$ Hroud ${ }^{h}$ OS \\
\hline 68. road & *potb & *pintis & ${ }^{*}$ póntō $h_{2} s$ & *Heitr \\
\hline 69. root & *kory & *šaknis & ${ }^{*} w r\left(h_{a}\right) d-$ & *wrHd- \\
\hline 70. round & *kroglb(jb) & *apwalus & *serk- & - \\
\hline 71. sand & *pěsbkb & - & ${ }^{*}{ }_{S a m h} h_{x} d h o s$ & ${ }^{*}$ samd ${ }^{h}$ os \\
\hline 72. say & ${ }^{*}$ rekti & ${ }^{*}$ sekti & ${ }^{*} w_{e k}{ }^{w}$ & ${ }^{*} w_{e k}{ }^{w}$ \\
\hline 73. see & *widěti & *weid- & ${ }^{*} \operatorname{der} \hat{k}-$ & *weid- \\
\hline 74. seed & *sěmę & ${ }^{*}$ sètlom, *sèmen & ${ }^{*}{ }^{s e h} h_{1} m e n-$ & ${ }^{*}$ seHmen \\
\hline 75. sit & ${ }^{*}$ sěděti & ${ }^{*} s \bar{e} d-$ & *sed- & ${ }^{*}$ sed- \\
\hline 76. skin & ${ }^{*} k o z ̌ a$ & ${ }^{*} k j a u t \bar{a}$ & *péln- & ${ }^{*}(s)$ keuts \\
\hline 77. sleep & ${ }^{*}$ sbpati & *meig- & ${ }^{*}$ swep- & ${ }^{*}$ swep- \\
\hline 78. small, little & ${ }^{*}$ malb $(j b)$ & *mažas & *pau- & ${ }^{*}$ min- \\
\hline 79. smoke & ${ }^{*} d y m b$ & *dūmas & *dhuh ${ }_{2}$ mós & ${ }^{*} d^{h} u$ Hmos \\
\hline 80. stand & ${ }^{*}$ stojati & ${ }^{*}$ stāti & $*(s)$ teh $_{2}$ & ${ }^{*} \mathrm{staH}-$ \\
\hline 81. star & *gwězda & *žwaižde & *h $h_{2}$ stér & ${ }^{*} x$ sters \\
\hline 82. stone & *kamy & *akmōn & *h $h_{4} e ́ \hat{e} m \bar{o} n$ & $* a \hat{k} m o n s$ \\
\hline 83. sun & ${ }^{*}$ sblnbko & *sāule & *séh ${ }_{a} u l$ & ${ }^{*} \mathrm{seHul}$ \\
\hline 84. swim & *pluti & *plaunkti & *pleu- & *snaH- \\
\hline 85. tail & *xwostb & *ōdegā & ${ }^{*} p u k\left(e h_{a}\right)-$ & ${ }^{*} p u k-$ \\
\hline 86. that & ${ }^{*} t b,{ }^{*}$ ont & *tas, *anas & $*_{\text {sO }}$ & *so, *onos \\
\hline 87. this & ${ }^{*} s b$ & *šis & *kis & $* \hat{k}$ is \\
\hline 88. tongue & ${ }^{*} e ̨ z y k b$ & *dinžuwis & ${ }^{*} d n g h u h_{a^{-}}$ & ${ }^{*} d_{o} \hat{g}^{h} u$ \\
\hline 89. tooth & ${ }^{*} z Q b b$ & *dantis & *h $h_{1}$ dónt- & ${ }^{*}$ Hdonts \\
\hline 90. tree & *derwo & ${ }^{*}$ derwa $/{ }^{*}$ dorwā & *dóru & *doru \\
\hline 91. two & ${ }^{*} d b w a$ & $* d \underline{u} \bar{o}$ & ${ }^{*} d w e h_{3}(u)$ & ${ }^{*} d(u) w o H$ \\
\hline 92. warm & ${ }^{*}$ teplo $(j b)$ & *šiltas & ${ }^{*} g^{w}$ hermós & ${ }^{*} t e p-$ \\
\hline 93. water & *woda & *wadōn & *wódr & *wodr \\
\hline 94. we & ${ }^{*} m y$ & ${ }^{*}$ mes & *wéi & *wei, *mes \\
\hline 95. what & $*_{c} b$ & *ka & ${ }^{*} k^{w} i d$ & ${ }^{*} k^{w} i d$ \\
\hline 96. white & *bělb(jb) & *baltas & ${ }^{*} h_{4} e l b^{h} o ́ s$ & ${ }^{*} x r \hat{g}-/{ }^{*} x a r \hat{g}-$ \\
\hline 97. who & ${ }^{*} k b$ & *kas & ${ }^{*} k^{w} o ́ s$ & ${ }^{*} k^{w}$ OS \\
\hline 98. woman & *žena & *genā & ${ }^{*} g^{w} e ́ n h_{a}$ & ${ }^{*} g^{w}$ ens \\
\hline 99. yellow & $* z ̌ b l t b(j b)$ & *geltas & *ghel- & ${ }^{*} g^{h} e l-$ \\
\hline 100. you & *ty & ${ }^{*} t \bar{u}$ & ${ }^{*}$ túh & ${ }^{*} t u H /{ }^{*} t u$ \\
\hline
\end{tabular}

Праиндоевропейский стословник составлялся с опорой на список Д. Адамса, однако нами были внесены некоторые исправления и уточнения. Составление праиндоевропейского списка Сводеша с подробным разбором всех потенциальных кандидатов требует отдельной обстоятельной работы, поэтому в данной статье мы ограничимся кратким разбором некоторых пунктов: 
All. Как нам кажется, предпочтение стоит отдать корню *pant, поскольку он обнаруживается в географически разделённых языках (греческий, фригийский и тохарские) и у него значительно меньше шансов быть инновацией, чем у корня * wi, который мы находим в языках-соседях (индоиранские и балтославянские).

Bark. Адамс принимает для этого пункта корень *loubho/eha. Однако есть основания считать, что корень *kor-является более подходящим кандидатом для праиндоевропейского названия коры. Оба этих корня сохранились в славянских языках и латыни. Для праславянского восстанавливаются *lubь [ЭССЯ, 16: 156-158] и *kora [ЭССЯ, 11: 44-45], имеющие продолжение в русских «луб» и «кора» с тем же значением. В латыни мы находим cortex - 'the outer covering of a tree, bark' [OLD: 451] и liber - 'the inner bark of a tree, rind, bast' [OLD: 1024]. Маловероятно, чтобы такое соответствие значений было случайным. По всей видимости, оно отвечает праиндоевропейскому состоянию. У корня *kor- есть ностратическое соответствие, имеющее именно такое значение [ОСНЯ, 1: $341-$ 343]. В то же время корень *loub- соотносится Илличем-Свитычем с ностратическим «ободранная кора» [ОСНЯ, 2: 33-34].

Breast. Адамс помещает под этот пункт списка лексемы, значение которых он реконструирует как «женская грудь», однако, согласно критериям из [Kassian et al.: 54], в список Сводеша должны вноситься слова, имеющие значение «грудь вообще», поэтому мы заносим в список лексему *perkus.

Green. Поскольку для древнейших состояний хеттского, санскрита и древнегреческого зафиксирована жёлто-зелёная система цветообозначений (hahhal-uwant-/hahli-want,

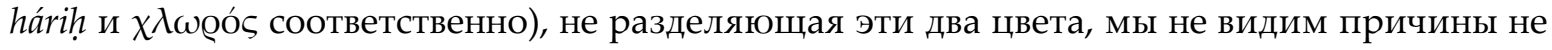
проецировать ту же систему на праиндоевропейский язык и не восстанавливать корень * $\hat{g}^{h} e l-$ «жёлтый/зелёный».

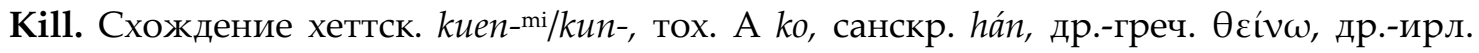
gonim [Pokorny, 1959: 491-493], означающих «убивать», практически не оставляет сомнений, что именно корень ${ }^{*} g^{w h} e n-$ употреблялся в праиндоевропейском языке в данном значении.

Man. Между двумя потенциальными обозначениями мужчины (*wiHros и ${ }^{*}$ Hners) выбор сделать довольно тяжело. Оба слова представлены в индо-иранских, валлийском и умбрском языках. В санскрите они противопоставлены следующим образом: narah 'a man, a male, a person, husband, hero' (мужчина, человек, муж, герой) [Monier-Williams, 1899: 628]; virah - 'a man, (esp.) a brave or eminent man, hero, chief' (человек, (особенно) храбрый или выдающийся человек, герой, вождь) [Monier-Williams, 1899: 1005]. Обратную картину мы наблюдаем в средневаллийском языке, где ner - 'chief, hero' (вождь, герой) [Matasović, 2009: 289], a gwr - 'man’ (мужчина) [Matasović, 2009: 423]. Данные умбрского языка, похоже, также говорят в пользу того, что *Hners было более поэтичным словом, чем *wiHros, поэтому в список мы вносим последнее.

Man (person). В данном случае приходится выбирать между ${ }^{h} d^{h} h$ mons (италийская, кельтская, германская и балтийская группы) и *manus (индоиранская, германская и славянская группы). Как географическое распределение, так и прозрачная мотивированность первого слова (от ${ }^{*} d^{h} \hat{g}^{h} e m s$ «земля») говорят в пользу большей древности второго.

Meat. Вместо введённого Адамсом пункта 'flesh' мы сохраняем стандартное 'meat' .

Rain. На роль праиндоевропейского названия дождя претендуют корни *suH- и *wers. Производные от ${ }^{*}$ suH- в основном значении «дождь» фиксируются в тохарских (тох А. swase, тох. В. swese), древнегреческом (v́ctós), албанском (shi) и прусском (suge) языках. *wers- в значении «дождь» выступает только в санскрите (varsáh), в близком к нему значении «ливень» в шотландском (fras), а также в древнегреческом ह̌ бๆ «роса» и хеттском 
warša- «туман». Тохарско-греческо-албанско-прусское схождение в семантике корня *suH- говорит в пользу того, что именно он в праиндоевропейском обозначал «дождь».

Road. В отличие от Адамса, вносящего в список слово «тропа», мы оставляем в нём более традиционное «дорога», которое для праиндоевропейского можно реконструировать как гетероклитическую основу *Heitr на основании схождения хеттск. itar «путь», тох. А ytār, тох B. ytārye «путь, дорога» и лат. iter «путь, поездка, дорога, тропа» [Pokorny, 1959: 294-295].

Round. Разнобой в разных ветвях индоевропейской семьи заставляет серьёзно усомниться в возможности реконструкции прилагательного «круглый» для праязыка.

See. Адамс восстанавливает для этого пункта корень *derk, представленный санскр.

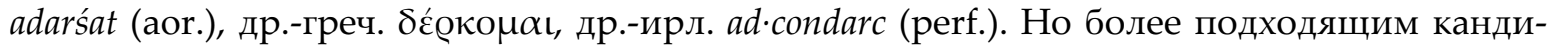
датом кажется *weid, сохранившийся в основном значении «видеть» в славянских и балтийских языках, в лат. videō и др.-греч. * $\varepsilon \grave{\delta} \delta \omega$, в производном от него «искать» - в санскр. vindati, арм. gtanem, др.-ирл. ro.finnadar «обнаружить», и широко распространённый в перфектном значении «знать» [Pokorny, 1959: 1125-1127].

Skin. Наиболее вероятным кандидатом на праиндоевропейское обозначение «кожи» является *(s)keuts, которое сохранилось в основном значении «кожа»в лат. cutis,

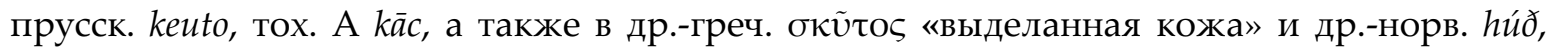
др.-англ. hyd, д.-в.-н. hut «кожа, шкура»

Small. На роль праиндоевропейского прилагательного «маленький» Адамс выдвигает корень *pau, отразившийся в лат. paulus, paucus и parvus «маленький», др.-греч.

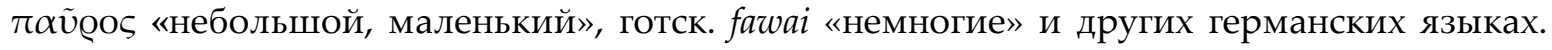
Как нам кажется, предпочтение стоит отдать *min, сохранившемуся в виде супплетивной

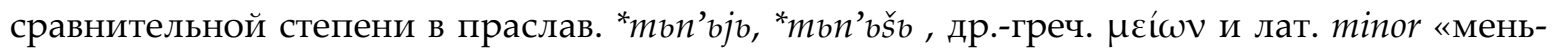
ший», а также в готск. mins «меньше», тох. Б. maiwe «маленький, молодой» и санскр. mināti «уменьшает».

Swim. Два глагола, *plew- и *snaH-, могут претендовать на статус праиндоевропейского слова со значением «плавать». Оба широко распространены в индоевропейских языках и, несомненно, восходят к праязыку, что означает, что в праязыке между ними была определённая семантическая разница. Вероятно, такое изначальное различие в семантике этих глаголов демонстрирует древнегреческий, где $v \eta ́ \chi \omega-$ активное действие ('swim'), а тлغ́㇒ - пассивное ('float') [Кисилиер, 2007: 374].

Warm. В данном случае Адамс помещает в список слово со значением 'hot' «горячий», однако стандартный стословный список Сводеша предусматривает 'warm' «тёплый». Поэтому в список следует скорее внести корень *tер. Тем не менее было бы нелишним рассмотреть разницу в семантике между производными от корней ${ }^{*} t e p-$ и ${ }^{*} g^{w h} e r-$ в тех языках, где полноценно сохранились оба корня, то есть в санскрите, латыни, бретонском и славянских языках. В санскрите мы находим gharmáh - 'heat, warmth (of the sun or fire), 'sunshine' (жар, тепло (солнца или огня), солнечный свет) [Monier-Williams, 1899: 376]; 'heat (both of sun and of fire)' (жар (как солнца, так и огня)) [MacDonell, 1893: 89] и tapah - 'consuming by heat' (пожираемый пламенем); 'burning' (горящий, пылающий) [MacDonell, 1893: 107]. В латыни зафиксированы formus - 'warm, hot' (тёплый, горячий) [OLD: 745] и tepidus - 'having a warm, but not hot temperature' (имеющий тёплую, но не горячую температуру) [OLD: 1923]. В бретонском обнаруживаются tomm - 'chaud' (тёплый, горячий) и gor - '(très) chaud' ((очень) тёплый, горячий). В славянских противопоставлены прилагательные, характеризующие предметы с меньшей температурой (например, рус. тёплый, польск. ciepty, чешск. teplý) и с большей (рус. горячий, польск. goracy, чешск. horký). Как нам кажется, латинско-бретонско-славянское схождение говорят в 
пользу того, что «тёплый» в праиндоевропейском языке обозначался словом, производным именно от корня *tер-.

White. Наиболее вероятный кандидат, обнаруживающийся в основном значении в хеттском (harki-/hargai), тохарских (А. ārki, В. ārkwi), санскрите (árjunah) и близком к основ-

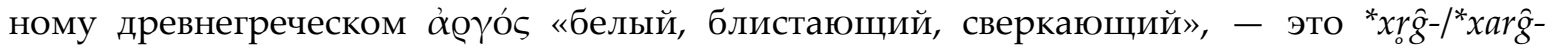
[Pokorny, 1959: 64-65].

Получившиеся сопоставления можно разделить на пять групп:

1. Праиндоевропейские корни, сохранившиеся в праславянском и прабалтийском: black, breast, burn, die, drink, dry, ear, earth, eat, eye, fire, full, give, go, green, heart, I, know, long, louse, meat, moon, mouth, nail, name, new, night, nose, not, one, see, seed, sit, smoke, stand, sun, that, this, tongue, tree, two, water, we, what, who, woman, you. Всего 47.

2. Инновации в праславянском при сохранении исходных лексем в прабалтийском: belly, blood, cloud, dog, fish, foot, liver, man, red, skin, tooth. Всего 11.

3. Инновации в прабалтийском при сохранении исходных лексем в праславянском: bark, cold, egg, hear, mountain, sleep, small, warm. Всего 8.

4. Независимые инновации в обеих группах: big, bone, good, kill, leaf, lie, man (person), many, neck, root, say, tail. Всего 12.

5. Общие инновации: all, ashes, bird, bite, come, fat, hand, head, horn, knee, road, star, road, white. Всего 14 (7 из которых слов входит в сокращённый пятидесятисловный список Г. С. Старостина).

Принимается, что для учёта пары слов как общей инновации достаточно совпадения корня, поэтому, например, общими инновациями мы считаем пары *pepelø/* popelø и *pelena- или *běltb и *baltas (< ${ }^{*} b^{h} H$ ltos, как лит. stãtas, statà и лтш. stats «ряд снопов» < *stHtos). Но следует отметить, что в парах all, fat, hand, head, horn праславянские и прабалтийские лексемы полностью совпадают по морфологическому составу.

Из подсчёта исключены 5 пунктов списка, в силу того что их не удалось восстановить: «перо», «лететь», «волос», «песок» (для прабалтийского) и «круглый» (для праиндоевропейского). Как заимствование в праславянском исключено слово «дождь». Как кентумные заимствования, в праславянском и в прабалтийском, - слова «камень» и «жёлтый».

Из 14 общих инноваций не все являются эксклюзивными. Так, «голова» и «кусать» находят параллели в армянском, «видеть»в латыни, «плыть» и «весь»в индоиранских языках, «дорога» в греческом, германских и индоиранских языках. Такое положение вещей вызвано сложным характером распада праиндоевропейского языка: подобные ситуации обнаруживаются и при сравнении стословных списков славянских языков с праславянским, а романских с латынью. Таким образом, если предполагать, что до существования балтославянской общности был период балто-славяно-арийского единства, то пары 1 'all', 68 'road' и 84 'swim' должны быть исключены из рассмотрения. С высокой долей вероятности инновация 15 'соте' может быть результатом параллельных и независимых процессов.

У всех инноваций имеются индоевропейские этимологии (таким образом, это не может быть случаем массированных заимствований из неизвестного источника в оба праязыка). Наиболее надёжными являются этимологии для 'соте' (дериват от *еi- «идти»), 'road' (сдвиг значения «тропа»> «дорога»), 'swim' (расширение значения корня *plew- 'float' > 'swim') и 'white'. В последнем случае как прабалтийское *baltas, так и праславянское *bělı являются производными от корня ${ }^{*} b^{h} e H-$ «блестеть, сиять». Праславянское ${ }^{*} b e ̌ l t b ~<{ }^{*} b^{h} H$ los является отглагольным прилагательным, образованным непосредственно от этого корня, а прабалтийское *baltas < * $b^{h} H$ ltos - причастием от производного глагола * $b^{h} \mathrm{OHl}$ - «белеть» [Саенко, 2012]. 
Менее надёжны этимологии слов 'ashes' (от *pel- «гореть» с частичной редупликацией [Boryś, 2005: 463; Smoczyński, 2007: 447-448]), 'bite’ (от *keHd, ср. санскр. khádati «есть,

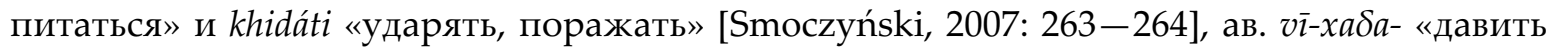
друг друга», н.-перс. xāyīdan «жевать» [Mayrhofer, 1992: 451-452], арм. хасапет «кусать, жалить» [Martirosyan, 2010: 323-324]), 'fat' (от *tеuH- «набухать, пухнуть» [Рokorny, 1959: 1081]), 'hand' (от *wrenk- «собирать», ср. лит. riñkti «собирать» [Boryś, 2005: 514; Smoczyński, 2007: 499]), 'fat' (от * $k^{w} e l H$ - «вращаться» или *kel- «подниматься» [ЭССЯ, 10: 132-134]) и 'star' (из имеющихся этимологий наиболее правдоподобной следует признать образование данного слова от ${ }^{*} \hat{g}^{h}$ woi-, ср. др.-греч. фоїßо «сияющий, сверкающий», прусск. swäigstan «свет», Асc. sg.) [ЭССЯ, 7: 181-183]).

Слабыми следует признать этимологии слов 'all' (от *wi- «врозь» [Pokorny, 1959: 1175-1176]), 'bird' (от *рu- «маленький, молодой» [Pokorny, 1959: 842-843]), 'head' (сопоставляется с арм. glux «голова» и п.-и.-е. ${ }^{*} g^{h}$ eluHs «черепаха» [ЭССЯ, 6: 221-222]) и 'horn' (возводится к *regh- «подниматься, выпрямляться» [Rix, 2001: 498]).

14 общих инноваций (10 в более строгом варианте) в стословном списке - это довольно большая цифра, которая может служить веским доводом в пользу существования периода балтославянского единства. Для сравнения: 13 общих инноваций разделяют болгарский и македонский язык по сравнению с праславянским, 8 - русский и украинский, 10 - датский и исландский по сравнению с прагерманским.

\section{Питература}

Балтийские языки - Языки мира: Балтийские языки. М.: Academia, 2006. [Yazyki mira: Baltiyskie jazyki. M.: Academia, 2006.]

Горнунг 1958 - Горнунг Б. В. К дискуссии о балто-славянском языковом и этническом единстве // Bопросы языкознания, № 4, 1958. С. 55-62. [Gornung B. V. K diskussii o balto-slavyanskom yazykovom i etnicheskom yedinstve // Voprosy yazykoznaniya, № 4, 1958. S. 55-62.]

Горнунг 1963 - Горнунг Б. В. Из предыстории образования общеславянского языкового единства. М.: Издательство АН СССР, 1963. [Gornung B. V. Iz predystorii obrazovaniya obshcheslavyanskogo yazykovogo yedinstva. M.: Izdatel'stvo AN SSSR, 1963.]

Дини 2002 - Дини П. Балтийские языки. М.: ОГИ, 2002. [Dini P. Baltiyskie yazyki. M.: OGI, 2002.]

Кисилиер 2007 - Кисилиер М. А. Перемещение в воде в древнегреческом языке // Глаголь движения в воде: лексическая типология. М.: Индрик, 2007. С. 351-379. [Kisilier M. L. Peremeshchenie v vode v drevnegrecheskom yazyke // Glagoly dvizheniya v vode: leksicheskaya tipologiya. M.: Indrik, 2007. S. 351-379.]

Лер-Сплавинский 1964 - Лер-Сплавинский Т. О северо-восточных окраинах праславянского языка // Вопросы языкознания, №1, 1964. С. 134-136. [Ler-Splavinskij T. O severo-vostochnykh okrainakh praslavyanskogo jazyka // Voprosy yazykoznaniya, №1, 1964. S. 134-136.]

Мартынов 2004 - Мартынов В. В. Язык в пространстве и времени. К проблеме глоттогенеза славян. М.: УРСС, 2004. [Martynov V. V. Jazyk v prostranstve i vremeni. K probleme glottogeneza slavyan. M.: URSS, 2004.]

Паучюте 1989 - Лаучюте Ю.-С. А. О методике балто-славянских исследований // Славяне. Этногенез и этническая история. А.: Издательство Ленинградского университета, 1989. С. 31-37. [Lauchyute Yu.-S. A. O metodike balto-slavyanskikh issledovanij // Slavyane. Etnogenez i etnicheskaya istoriya. L.: Izdatel'stvo Leningradskogo universiteta, 1989. S. 31-37.]

ОСНЯ - Иллич-Свитыч В. М. Опыт сравнения ностратических языков: Сравнительный словарь. Тома I-III. М.: Наука, 1971-1984. [Illich-Svitych V. M. Opyt sravneniya nostraticheskikh yazykov: Sravnitel'nyj slovar'. Toma I-III. M.: Nauka, 1971-1984.]

Саенко 2012 - Саенко М. Н. Реконструкция этимологического значения праслав. *bе̌lь // Северное Причерноморье: к истокам славянской культуры. Киев / Москва / Феодосия, 2012. С. 56-59. [Saenko M. N. Rekonstrukciya etimologicheskogo znacheniya praslav. *bělı // Severnoe Prichernomor'ye: $k$ istokam slavyanskoj kul'tury. Kiev / Moskva / Feodosiya, 2012. S. 56-59.] 
Саенко 2013а - Саенко М. Н. Реконструкция праславянского списка Сводеша // Вопросы языкового родства. 2013. № 10. C. 139-148. [Saenko M. N. Rekonstrukciya praslavyanskogo spiska Svodesha // Voprosy yazykovogo rodstva. 2013. № 10. S. 139-148.]

Саенко 20136 - Саенко М. Н. Реконструкция прабалтийского списка Сводеша // Известия Южного федерального университета. Филологические науки. 2013. №2. С. 60-66. [Saenko M. N. Rekonstrukciya prabaltiyskogo spiska Svodesha // Izvestiya Juzhnogo federal’nogo universiteta. Filologicheskie nauki. 2013. №2. S. 60-66.]

Соболевский 1922 - Соболевский А. И. Русско-скифские этюды (окончание) // Известия ОРЯС РАН. 1922 г. T. XXVII. C. 252-332. [Sobolevskij A. I. Russko-skifskie etyudy (okonchanie) // Izvestiya ORYaS RAN. 1922 g. T. XXVII. S. 252-332.]

ЭССЯ - Этимологический словарь славянских языков. Выпуски 1-38. М.: Наука, 1974-2012. [Etimologicheskij slovar' slavyanskih yazykov. Vypuski 1-38. M.: Nauka, 1974-2012.]

Adams, Mallory 2006 - Adams D. Q., Mallory J. P. The Oxford Introduction to Proto-Indo-European and IndoEuropean World. Oxford: Oxford University Press, 2006.

Blažek, Novotná 2007 - Blažek V., Novotná P. Glottochronology and its application to the Balto-Slavic languages. Baltistica XLII (2-3), 2007. Pp. 185-210, 323-346.

Boryś 2005 - Boryś W. Słownik etymologiczny języka polskiego. Kraków: Wydawnictwo Literackie, 2005.

Girdenis, Mažiulis 1994 - Girdenis A., Mažiulis V. Baltų kalbų divergencinė chronologija. Baltistica XXVII (2), 1994. P. 4-12.

Kassian et al. - Kassian A., Starostin G., Dybo A., Chernov V. The Swadesh wordlist. An attempt at semantic specification // Вопросы языкового родства, №4. Pp. 46-89.

MacDonell 1893 - MacDonell A. A Sanskrit-English Dictionary. Oxford: Clarendon Press, 1893.

Mayrhofer 1992 - Mayrhofer M. Etymologisches Wörterbuch des Altindoarischen. I. Band. Heidelberg: Carl Winter Universitätsverlag, 1992.

Martirosyan 2010 - Martirosyan H. K. Etymological Dictionary of the Armenian Inherited Lexicon. Leiden: Brill, 2010.

Matasović 2009 - Matasović R. Etymological Dictionary of Proto-Celtic. Leiden / Boston: Brill, 2009.

Meillet 1908 - Meillet A. Les dialectes indoeuropéens. Paris: Librairie Ancienne Honoré Champion, 1908.

Monier-Williams 1899 - Monier-Williams M. A Sanskrit-English Dictionary. Oxford: Clarendon Press, 1899.

OLD - Oxford Latin Dictionary. Oxford: Oxford University Press, 1968.

Pisani 1969 - Pisani V. Baltisch, Slavisch, Iranisch // Baltistica, V (2), 1969. Pp. 133-140.

Pokorny 1959 - Pokorny J. Indogermanisches etymologisches Wörterbuch. Bern / München, 1959.

Rix 2001 - Rix H. Lexikon der indogermanischen Verben. Wiesbaden: Dr. Ludwig Reichert Verlag, 2001.

Rozwadowski 1961 - Rozwadowski J. O pierwotnym stosunku wzajemnym języków bałtyckich i słowiańskich // Wybór pism. Tom II. Warszawa: PWN, 1961. S. 96-113.

Smoczyński 2007 - Smoczyński W. Słownik etymologiczny języka litewskiego. Wilno: Printer Polyglot, 2007.

Zeps 1985 - Zeps V. Is Slavic a West Baltic Language // General Linguistics, Vol. 24, № 4, 1985. Pp. 213 -222.

Mikhail Saenko. Innovations in the Proto-Baltic and Proto-Slavic Swadesh lists as an argument in the discussion on Balto-Slavic genetic unity.

The paper represents an attempt to compare the Swadesh lists for Proto-Slavic and Proto-Baltic with the Swadesh list for Proto-Indo-European, with the general aim of establishing common Balto-Slavic innovations. The applied methodology relies on the fact that genetic unity of a group of languages should be reflected in the form of common innovations pervading all the levels of the language, including the lexicon. Consequently, it is reasonable to take into account not the entire number of matches on the Swadesh list in order to determine the degree of relationship, but only those matches that may be assumed to represent such common innovations. The comparison of 100 -wordlists constructed for ProtoSlavic and Proto-Baltic has led to the discovery of up to 14 common innovations (or at least 10, if a more rigorous approach is applied). The author argues that this should be considered a solid argument in favor of assuming a period of Balto-Slavic unity.

Keywords: lexicostatistics, Slavic languages, Baltic languages, Proto-Indo-European language 